\title{
1. Introduction to concepts and dramatis personae
}

\subsection{SETTING THE SCENE}

The aim of the study is to focus on how the well-established corporate governance debate can be applied to firms (and in particular small firms) experiencing financial distress. This aspect of the broader governance discourse is less well documented than the usual scenario applicable in the case of listed solvent concerns. Tens of thousands of firms of all sizes in the UK endure this debilitating economic condition each year ${ }^{1}$ and it is important that we understand the regulatory context in which they, their managers, their 'gatekeepers' 2 and ultimately their undertakers ${ }^{3}$ have to subsist. The macro-economic climate prevailing in 2011 and 2012 has been especially testing and has consequently thrown up this issue into sharp relief. But we should not be over-alarmist because if we refer to Companies House Annual Companies Statistics for 2011-12, we find in Table A1 some 2663100 companies registered in England and Wales. Table A4 from the same source tells us that the average life span of a limited company is 8.8 years.

The research methodology to be adopted in this study is primarily doctrinal in nature (but including usage of some comparative material). Nevertheless, it has been supported by insights collected from fellow academics and practitioners via many a discussion in recent years. I am grateful to those practitioners and experts who have spared the time to share their thoughts with me,

1 Figures for 2011 show 21843 companies entering formal insolvency proceedings in England and Wales. In the EU some 220000 companies were liquidated in 2010 - see Consultation on Future of European Insolvency Law (21 June 2012). But that is only the tip of the iceberg; many thousands of businesses teeter on the brink of insolvency each year but manage to survive on a hand-to-mouth basis. Such companies are increasingly referred to as 'zombie' companies - see L. Manning [2012] (Winter) Recov 5. It is sometimes suggested that banks are too concerned at the present about the amount of bad debt on their balance sheets to precipitate the formal insolvency of such firms.

2 See John Coffee, Gatekeepers: The Professions and Corporate Governance (2006) - this term is wide enough to cover auditors and professional advisers.

3 That is, insolvency office-holders. 
though I stress that the views expressed in this text are my personal insights, for which I take sole responsibility. The author was fortunate enough to be awarded a six-month visiting fellowship at the Institute of Advanced Legal Studies in London in the first half of 2012 to facilitate research into the stewardship aspects of this project.

The study is 'dynamic' in the sense that it will observe and analyse the changing goals of governance as the financial well-being of the company declines. It will become apparent that the stewardship emphasis switches from a primary (but no longer exclusive) focus on the protection of shareholders to the safeguarding of other stakeholder groups (especially creditors and employees). The pivotal role of banks in their capacity as secured creditors in this changing financial environment will attract particular attention.

A historical perspective will be included, and the question will be asked whether the dominant theories and rules operating in this field are appropriate to the challenging social and economic conditions encountered by company stewards in the early decades of the twenty-first century in the wake of the global economic crisis that first hit us badly in the latter part of $2008 .{ }^{4}$ Should we adopt a more sympathetic approach towards those who struggle to keep companies afloat against a combination of adverse trading conditions? Alternatively, should we move away from the current vogue for attempting business rescue and instead embrace the potential opportunities generated by the forces of destructive economics $?^{5}$ More radically, is it now an opportune time to reconsider our liberal approach towards the general availability of limited liability to all entrepreneurs? ${ }^{6}$ When set against the very high mortality rate for new SMEs, this is surely not an outlandish question to ask, though for those wedded to established ideas, this is tantamount to a heresy.

The author will consider whether the current UK regime for the governance of distressed firms is adequate and will examine the implications of making

4 For an excellent account of this global event see C.A.E. Goodhart, The Regulatory Response to the Financial Crisis (2010) (Edward Elgar) and L.E. Mitchell and A.E. Wilmarth, Jr, The Panic of 2008 (2010) (Edward Elgar).

5 See the work of Joseph Schumpeter, in particular The Theory of Economic Development: an Inquiry into Profits, Capital, Credit, Interest and the Business Cycle (1934). This work was first produced in German in 1912, but did not receive global attention until translated into English in 1934. The idea of creative destruction was more to the fore in Schumpeter's later text Capitalism, Socialism and Democracy (1942). See also P. Ormerod, Why Most Things Fail: Evolution, Extinction and Economics (2005). Schumpeter's wide-ranging work can be applied to the corporate governance debate in a number of ways - see for example A. Belcher [1996] 47 NILQ 322 .

6 See A. Hicks [1997] JBL 306 and [2001] JBL 433. Further discussion of this vital issue is provided by S. Griffin (2004) 25 Co Law 99 and B. Pettet [1995] CLP 124. 
changes in this area (for example by enhancing recoveries for creditors and promoting measure for the rescuing of firms). Those changes may well be informed by the experience of other jurisdictions in dealing with common problems (see Chapter 5). But caution must be exercised here, as we shall discover.

This is an important area for study because, with the reality of globalization, it is vital that the UK is seen to have effective rules operating in this area, as those many foreign companies who are now taking advantage of our insolvency procedures may have migrated here solely for the exploitation of that limited tactical purpose. ${ }^{7}$ Allowing regulatory inefficiencies to develop in the way we tackle insolvent companies could stultify this development, which provides valuable employment and income for the professional services sector, and could thereby damage the UK economy as a whole. The World Bank has commented favourably upon the relative efficiency of using insolvency processes in the UK. ${ }^{8}$ Under the 2012 survey the UK ranks sixth in the world. That said, we should not prostitute fundamentals (such as basic tenets of distributional justice and essential ethical standards of stewardship) simply to attract the business associated with foreign bankruptcies; in other words, we should resist the temptation to become the 'bankruptcy brothel of Europe', as some critics have alleged.

\section{2 'CORPORATE GOVERNANCE’ DEFINED}

We need to explain what we mean by the term 'corporate governance' for the purposes of this project. Corporate governance theory will be analysed in Chapter 2. In the context of a corporate entity, various definitions of corporate governance are available. ${ }^{9}$ There is no agreement here on the precise wording of a definition but there exists a broad consensus on what we are talking about.

7 We thus have the 'bankruptcy tourism' syndrome - see for example Hellas Telecommunications (Luxembourg) II SCA [2009] EWHC 3199 (Ch), [2010] BCC 295 (foreign company relocated to this jurisdiction to use controversial prepack procedure under the umbrella of an administration). For later proceedings involving a dispute as the most appropriate exit route from administration see [2011] EWHC 3176 (Ch), where the actions taken in the administration were upheld. Compare Hans Brochier Holdings v Exner [2006] EWHC 2594 (Ch), [2007] BCC 127, where the English courts eventually declined to claim jurisdiction because the evidence suggested that the centre of main interests (COMI) of the company was located in Germany.

8 See World Bank, Doing Business (2012). Note also A. Reisberg [2010] CLP 315.

9 See A. Keay, Directors' Duties (2009) at paras 3.02-3.10. 
The Cadbury Committee ${ }^{10}$ viewed corporate governance in terms of a system which operates to control and direct companies. Giles Proctor and Lilian Miles also lay emphasis on the element of systems. ${ }^{11}$ John Parkinson in a posthumous essay ${ }^{12}$ helpfully described the notion as having both internal and external aspects, in the sense that it encompasses both domestic governance elements and external regulation of companies. More recently, Alan Dignam and Michael Galanis explain corporate governance in terms of an institution that weighs up competing stakeholder interests. ${ }^{13}$ The perspective favoured by the OECD is also one that focuses upon the relationship that exists between the board and the various stakeholder constituencies. Generally, North American perspectives focus on the relationship between boards and their shareholders, whereas European analyses tend to take in the wider stakeholder interest.

Taking all of these useful perspectives into account, at the end of the day the working definition we have adopted for this survey is:

That system of legal rules and other social norms that seeks to regulate how firms are managed in the interests of the appropriate stakeholders.

This definition is wide enough to encompass material that exists beyond the law (such as codes of practice, conventions and social norms); it also invites us to consider who are the appropriate stakeholders at any one point in time. The definition is not restricted to the governance of companies, but would be capable of applying to other entities, such as LLPs, whose members enjoy the characteristic attribute of limited liability.

If we are to focus on systems of regulation, we should now identify the essential components of this governance system. This is not always entirely clear. As far as English law is concerned, we will be looking at legislation (in its various forms), European measures (both EU and ECHR ${ }^{14}$ related) and jurisprudence developed by the courts. There is also a significant self-regulatory component, for example the UK Corporate Governance Code (introduced in 2010 and updated in September 2012). The courts in developing the law will clearly have recourse to principle but will also keep a keen eye on custom and practice to inform their decisions, particularly when reviewing the actions

10 (1992) at para 2.5.

11 See G. Proctor and L. Miles, Corporate Governance (2003) at 3.

12 See 'Corporate Governance and the Regulation of Business Behaviour' in $\mathrm{S}$. Macleod (ed.) Global Governance and the Quest for Justice: Vol 2 - Corporate Governance (2006).

13 See their Preface to The Globalisation of Corporate Governance (2009).

14 Now forming part of English law through the medium of the Human Rights Act 1998 . 
of insolvency practitioners. ${ }^{15}$ Lord Mansfield, the father of UK commercial law, would surely commend such an approach. Generally, we would expect the courts to be promoting the highest standards of stewardship, though they do enjoy discretion to 'whitewash' procedural lapses that do not negatively impact upon reasonable stewardship expectations. Witness their role on applications under s. 1157 of the Companies Act 2006 and in dealing with formal lapses in insolvency procedures. ${ }^{16}$ There is one negative feature of judicial input into the governance matrix that is worth flagging up at this early stage of the exercise. Judicial decisions are in effect a form of retrospective guidance in that they constitute a legal pronouncement upon conduct that has gone before. In a climate where legal uncertainty is not uncommon, this declaratory aspect of judicial decision-making can have serious consequences for insolvency practitioners and it is doubly important that the views within the profession as to the acceptability of a practice are taken account of (but not necessarily slavishly followed). Misconceptions on acceptable practices have a nasty habit of being converted into a form of orthodoxy with the result that disappointing judicial rulings receive unfair criticism. On the positive side, the prompt reporting of decisions through the neutral citation system and the agency of BAILII (British and Irish Legal Information Institute) have helped to mitigate some of the problems here. We return to this thorny issue in Chapter 6.

Moving on, the use of the concept of governance presupposes that someone is going to be governed. For the purposes of our study that subject group will be those who manage firms, whether such firms be with or without a formal insolvency regime.

\section{3 'FIRMS'}

A secondary definitional issue requires clarification. This study as suggested above will encompass governance regimes both in relation to limited companies and limited liability partnerships (LLPs). Both are corporate entities ${ }^{17}$

15 For recognition of this see G. Lightman (2001) 14 Ins Intell 57 at 70 . Also note the comments of Neuberger J in MTI Trading Systems $v$ Winter [1998] BCC 591 at 595 .

16 They have statutory authority to do this via Insolvency Rule 7.55. Note also the precedent of Re G Tech Construction Ltd [2007] BPIR 1275. On this see the discussion in Chapter 4.

17 See Limited Liability Partnerships Act 2000 s. 1(2). The similarity between companies and LLPs and the distinctions with the partnership form are borne out by Sales $\mathrm{J}$ in $F \&$ \& Alternative Investments $v$ Barthelemy [2011] EWHC 1731 (Ch), 
with sophisticated layers of legal regulation. So under the LLP Act 2000 basic rules of company law are introduced via s. 15 and basic rules of corporate insolvency law via s. 14 . The details of LLP regulation are found in secondary legislation, such as the LLP Regulations 2001 (SI 2001/1090) and the LLP (Application of the Companies Act 2006) Regulations 2009 (SI 2009/1804). The Practice Direction on Insolvency Proceedings ${ }^{18}$ treats LLPs as equivalent to a company for the purposes of its application, as is made clear in para 1.1(7). Both forms of organization enable the participators to operate a business or profession without incurring full personal liability for the firm's debts. Limited liability, in effect, triggers the stewardship question. We shall not therefore look at the general problem of insolvent partnerships (governed generally by the Partnership Act 1890), which are subject to specific regulation in the Insolvent Partnerships Order 1994 (as amended). ${ }^{19}$ For similar reasons we will not consider governance issues in relation to limited partnerships registered under the Limited Partnerships Act 1907 because the general partners do not enjoy limited liability and the limited partners are not allowed to manage (see s. 6(1) of the 1907 Act). That said, comparable insolvency procedures and the company directors' disqualification regimes are often made available to such firms.

Our study will also seek to pay particular attention to the position of SMEs, though not exclusively so. On a definitional point, the Companies Act 2006 characterizes SMEs in broad terms - so, for instance, under s. 382 a small company is defined as one in which two of the following three factors are present - turnover of less than $£ 6.5$ million, balance sheet total below $£ 3.26$ million and fewer than 50 employees. A medium-sized enterprise must, according to s. 465 , manifest two of the following three criteria - turnover less than $£ 25.9$ million, balance sheet total less than $£ 12.9$ million and fewer than 250 employees. Although there is no formal legal definition, we should also note the importance of micro-businesses, which typically have fewer than 10 employees. It is clear that many thousands of businesses will fall within these catchment areas. It has been estimated that some 20 per cent of the companies currently experiencing financial distress are micro companies.

We shall focus our study on companies that operate for profit, though it cannot be denied that many of the issues under examination are relevant to

[2012] 3 WLR 10 where he held at para [213] that members of LLPs do not (in the absence of express provision) owe fiduciary duties inter se, but rather to the firm itself. This point was confirmed by Hamlen $\mathbf{J}$ in Brown v InnovatorOne plc [2012] EWHC 1321 (Comm) at para [1304] - leave to appeal has been granted - see [2012] EWCA Civ 1587.

18 [2012] BPIR 409.

19 SI 1994/2421. See A. Bacon (1994) 10 IL \& P 166, S. Frith and B. Jones (1995) 11 IL \& P 14. 
those many charitable undertakings that experience financial distress. ${ }^{20}$ As a former director of such a social undertaking, I can attest to that.

There is some evidence that small firms have a greater propensity to fail than larger concerns. ${ }^{21}$ Within the EU we find quoted a 50 per cent failure rate in the first five years of corporate existence. The reasons for this relatively high mortality rate are varied. Commentators point to initial undercapitalization, a lack of managerial experience and the 'barriers to entry' into a market presented by competition from larger established firms as significant elements featuring in this high failure rate. There is no doubt that new companies face particular difficulties in their early years of operation. Large public companies tend to be established businesses with well-qualified managers and access to expert professional advice in a range of areas covering marketing, finance and IT. A distressed larger venture may present opportunities for restructuring this is often less likely the case at the SME end of the spectrum, where the options are more constrained. It may simply be easier to let such companies fail and (assuming there has been no managerial misbehaviour) for the entrepreneurs involved to try again with a new business armed with the benefits of a tough experience.

\section{4 'DIRECTORS'}

One of the central players in our study will be the company director. The director is the essential element in the running of a modern limited liability company. Historically the footprint of directors can be traced back to the earliest days of company law, but in reality they are a nineteenth-century entrant to the scene. They have their own representative organizations, ${ }^{22}$ which are effective lobbyists. Many MPs are, or will have been, or will become, company directors and this fact tends to reinforce their voice in policymaking. A few initial points of clarification are in order. First, under English law a

20 So the Charity Commission produced a booklet in 2000 entitled Managing Financial Difficulties and Insolvency in Charities. For legislative provision specifically directed towards the winding-up of charities, see Charities Act 2011 s. 113. The link with company law is enhanced with the introduction by the 2011 Act of charitable incorporated organizations, to which many of the standard insolvency provisions were applied by SI 2012/3013.

21 On this phenomenon see D. Milman and G. Cook [2002] 34 Manag Fin 34 and the material cited therein. There is a useful discussion provided by Y. Rotem in [2011] 20 IIR 131.

22 Such as the Institute of Directors (1903) and the Confederation of British Industry (1965) (which arose out of a merger of existing representative bodies). 
company director may surprisingly be another corporate entity. ${ }^{23}$ This is unusual in world corporate law systems, where the norm is to permit only natural persons to act in that capacity. ${ }^{24}$ This latitude on our part does cause some difficulties in practice where the law seeks first to identify and then affix a natural person with real legal responsibility. So, in the past, we have seen the syndrome of offshore companies acting as sole directors of English companies, thereby making a nonsense of domestic corporate regulatory policy. Even where there is no offshore element at work, the use of corporate directors in any stewardship model can cause problems for the regulators. Witness the case of HMRC v Holland, ${ }^{25}$ where the UK Supreme Court felt constrained to hold that an individual who was a director of a corporate director of Company A could not ipso facto be treated as a de facto director of Company A. ${ }^{26}$ Some 50 years

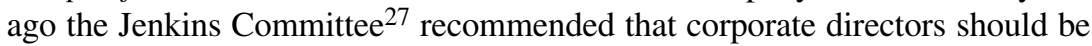
prohibited in English Law. The difficulties posed by corporate directors have eventually led Parliament to enact through the medium of s. 155 of the Companies Act 2006 a compromise ${ }^{28}$ requirement that a company must have in addition at least one natural person acting as a director, though the possibility of having corporate directors still remains available. By way of comparison, it should also be noted that a partnership cannot be appointed as a company director, ${ }^{29}$ though there is no objection to a limited liability partnership assuming that role as it enjoys separate legal personality. We could complete the circle here by pointing out that a company can be a partner, a member of an LLP or a limited partner in a limited partnership (see s. 4(4) of the 1907 Act).

23 See Re Bulawayo Markets and Office Ltd [1907] 2 Ch 458 and Companies Act 2006 s. 164 (which implicitly confirms the point). It follows therefore that a corporate director can be disqualified - see Official Receiver v Brady [1999] BCC 258. For the implications of the disqualification of a corporate director, see the comments of Floyd $\mathrm{J}$ in Secretary of State for BIS v Gifford [2011] EWHC 3022 (Ch).

24 See for example the prohibition imposed in Ireland - see Re Worldport Ltd [2009] 1 IR 398. Bizarrely, it seems that a company can be a shadow director in Ireland. The Irish prohibitive position mirrors that found in Australia, Malaysia, New Zealand, Singapore and South Africa. Developing jurisdictions such as Kazakhstan operate similar bars. But France appears to permit corporate directors as does The Netherlands to a limited extent. SMCLN 1.

[2010] UKSC 51, [2011] BCC 1. For comment see L. Sealy [2011] 287

26 See also Re Hydrodan (Corby) Ltd [1994] BCC 161. Note also s. 251(3) of the Companies Act 2006.

27 (1962, Cmnd 1749) para 85(d).

28 Similar compromises have been made in Hong Kong - see J.L. Yap [2012] JBL 579 at 581.

29 On this see Commercial Management Ltd $v$ Registrar of Companies [1987] 1 NZLR 744. 
There are other points to note. Company directors must be of a certain age of responsibility; a minimum age of 16 is now being specified by s. 157 of the Companies Act 2006 - why this is not fixed at 18 is hard to justify. But it is a move in the right direction as previously no minimum age was fixed. ${ }^{30}$ Indeed, formal educational/vocational qualifications are not required. Undischarged bankrupts are automatically disqualified by virtue of s. 11 of the Company Directors Disqualification Act 1986, though this disqualification has lost some of its bite with the progressive reduction of bankruptcy periods to a current maximum of one year. Similar bars contained in s. 11 apply to persons subject to debt relief orders, debt restriction orders or debt restriction undertakings. Such automatic disqualifications, although reinforced with criminal liability, ${ }^{31}$ are unlikely to fall foul of the European Convention on Human Rights. ${ }^{32}$ But there is no means test in operation linked to personal resources and no need to provide a minimum capital requirement in order to gain access to limited liability. Many private companies have share capital of less than $£ 100 .{ }^{33}$ Some 372500 of the 426500 new incorporations in 2011-12 featured such minimally capitalized enterprises according to Table B1 of the Companies House Annual Statistics for that year. There is no need to show experience in business, though banks asked to provide business finance might be interested in that matter. English law permits the most unskilled of persons to become a company director and then criticizes them if things do not work out. ${ }^{34}$ Gender, until recently, has not been seen as an issue - with the result that the overwhelming majority of directors of public companies are male. ${ }^{35}$ There is no
30 See Marquis of Bute's case [1892] 2 Ch 100.
31 See $R v$ Doring [2002] EWCA Crim 1695, [2002] BPIR 1204.
32 See Michael $v$ Official Receiver [2010] EWHC 2246 (Ch).

33 Hence the tendency towards 'incorporation tourism' as supported by the European Court of Justice in Centros (C212/97) [2000] Ch 446. This particular ruling led to hundreds of EU firms relocating their place of incorporation to the UK whilst continuing to trade with limited liability in their 'home' jurisdiction. This in turn led to a 'race to the bottom' in terms of a reduction of the minimum share capital requirement in Germany, France and Denmark for private companies. One wonders whether corporate stewardship in the EU has suffered here as part of the price of regulatory competition and the operation of the market in corporate charters.

34 See Re HHO Licensing Ltd [2007] BPIR 1363 and Re DKG Contractors Ltd [1990] BCC 903.

35 This has been criticized by Lord Davies in his report Women on Boards (February 2011). See editorial in [2011] 291 SMCLN 1. There has been some impressive scholarship on this broad issue - see for example M. McCann and S. Wheeler (2011) 38 Jo of Law and Soc 542. The DBIS has produced an update with the focus on the Voluntary Code of Conduct agreed with recruitment agencies - see BIS Press Notice 24 July 2012. Figures released in late 2012 suggest that for FTSE 100 companies the number of female directors is just over 17 per cent - see the Guardian, 1 
licensing system for company directors, though informal trade associations exist. It also follows that there is no in-house disciplinary model - the sanctioning of directors is a matter for the general law of the land and, in particular, for the shareholders themselves. Moreover, there is no need for a director of a UK company to have British nationality, or indeed to be resident in the jurisdiction. ${ }^{36}$ That said, the register of directors must by virtue of s. 163(1) of the Companies Act 2006 disclose details of nationality and residence. This disclosure is repeated in the context of the annual return by s. $855 \mathrm{~A}$ of the 2006 Act. As is the case with corporate directors, this latitude has the potential for posing difficulties for national regulatory policy. ${ }^{37}$ On the other hand, it at least avoids any clash with EU Law and the principle of free movement of services. ${ }^{38}$ Finally, we should note that the number of directorships one can hold is not capped by English law, though the courts will treat with some circumspection an assertion that an individual can give proper attention to a large number of companies under his stewardship. ${ }^{39}$

When we talk about directors, we need to distinguish three legally distinctive ${ }^{40}$ categories that are formally recognized in most corporate law jurisdic-

December 2012. This issue is now attracting the attention of EU regulators, where the issue of quotas has been raised. The Commission put a proposal for a 40 per cent quota to be introduced by 2020; we await developments in the EU as there is some opposition to a binding quota-based reform from a range of Member States. Certainly, there are unlikely to be EU-wide sanctions introduced for failure to comply. See Editorial [2012] 325 SMCLN 1.

36 A survey in 1996 showed that nearly 20 per cent of directors were non-resident. A number of wanted fraudsters, terrorists and war criminals are also apparently registered as company directors - see The Times, 21 February 2008 (p. 28). It was quite common in the past to find residents of Sark (which at that time had no system of company law itself) taking up UK company directorships in huge numbers - this was the so-called Sark Lark which featured in the judgment of Blackburne $\mathrm{J}$ in Official Receiver $v$ Vass [1999] BCC 516, where the individual at the time held some 1313 directorships in UK companies. For background details, see the Independent, 27 June 1999. As a result of a crackdown in Guernsey, the offshore nominee director phenomenon has simply moved offshore to various sites in the Caribbean and Indian Ocean. There is a residence requirement in Ireland but that can be waived in a range of circumstances.

37 For a sensible response by the English courts see Re Seagull Manufacturing Co Ltd [1993] BCC 241.

38 See TFEU Art 56 and cases such as Commission v Spain (C114/97) [1999] 2 CMLR 701 and Commission v Belgium (C355/98) [2000] 2 CMLR 357.

39 See the comments of the court in Re Kaytech International Ltd [1999] 2 BCLC 351.

40 As to whether they are mutually exclusive there is some dispute. For instance in Re Mea Corp Ltd [2006] EWHC 1846, [2007] 1 BCLC 618 Lewison J opined at para [89] that the categories of de facto and shadow director were not mutually exclusive. Other judges have been more sceptical. 
tions. Before doing that we should observe that a person is characterized (rather than defined) as a director in English law by reference to functions discharged and not by reference to title. ${ }^{41}$

The de jure director is the director who has been properly appointed to that position and is officially recorded as holding that status. That status is not affected by a relative lack of visibility or any degree of inactivity.

Second, a de facto director ${ }^{42}$ is a person (in the fullest sense of the word) who acts from the viewpoint of the outside world as if appointed as a de jure director. The functional element is apparent in this context. Visibility is also clearly relevant here. A useful indicator was suggested in Re Mumtaz Properties $L t d,{ }^{43}$ where the court asked the question whether the individual could be said to be part of the governance structure. As always, there are fine lines to be drawn here. So a consultant who is clearly operating as an independent contractor providing managerial consultancy input is unlikely to be labelled a de facto director. ${ }^{44}$

Third, we have the mysterious category of the shadow director. ${ }^{45}$ First appearing in 1917 via the Companies (Particulars as to Directors) Act of that year, this is a person in accordance with whose instructions the directors are accustomed to act. ${ }^{46}$ Professionals acting solely within their professional capacity are not thereby deemed to be shadow directors. ${ }^{47}$ So a gatekeeper who is advising the directors in times of corporate financial stress can do so without being enmeshed in the fate of the company. This is important to ensure that professionals can provide professional guidance in situations of corporate

41 See Companies Act 2006 s. 250, Insolvency Act 1986 s. 251 and Company Directors Disqualification Act 1986 s. 22(4).

42 On the identification of de facto directors see Gemma Ltd v Davies [2008] 2 BCLC 281, Apax Global Payment and Technologies Ltd v Morina [2011] EWHC 2983 (Ch), Re Mumtaz Properties Ltd [2011] EWCA Civ 610, [2012] 2 BCLC 109 and Re Snelling House [2012] EWHC 440 (Ch). For a penetrating discussion of the concept of a de facto director see C. Noonan and S. Watson [2008] JBL 587.

43 Re Mumtaz Properties Ltd (supra). $3148(\mathrm{Ch})$.

City of London Group plc v Lothbury Financial Services Ltd [2012] EWHC

45 See S. Griffin (2003) 54 NILQ 43 and his later piece in [2011] 24 Ins Intell 44. Note also C. Noonan and S. Watson [2006] JBL 763. For an Australian perspective see M.R. Hobson [1998] 10 Bond Law Rev 184. The South African position is reviewed by K. Idensohn in [2010] 22 SA Merc LJ 326.

46 Companies Act 2006 s. 251(1), Insolvency Act 1986 s. 251, Company Directors Disqualification Act s. 22(5). The Irish definition mirrors this terminology Companies Act 1990 s. 27. For recent discussion by David Richards J see his preliminary observations in McKillen v Misland (Cyprus) Investments Ltd [2012] EWHC 521 (Ch) and his judgment in [2012] EWHC 2434 (Ch) at paras [592]-[602].

47 Companies Act 2006 s. 251(2), Insolvency Act 1986 s.251, Company Directors Disqualification Act 1986 s. 22(5). 
crisis so that distressed companies are not left to face ruin without the prospect of assistance. Creditors using standard monitoring procedures would also appear to fall outside this shadow director status. This latter issue has been discussed in English law for some time ${ }^{48}$ and the banks (after initial concerns were expressed on their behalf ${ }^{49}$ ) now seem to know how far they can go before crossing the Rubicon. ${ }^{50}$ However, if creditors exceed normal levels of control there must be a risk of a shadow directorship issue arising. ${ }^{51} \mathrm{In}$ Australia the New South Wales Court of Appeal has supported monitoring rights in Buzzle Operations Pty v Apple Computer Australia Pty Ltd. ${ }^{52}$ As far as shareholders are concerned, Lewison J suggested in Re Mea Corp Ltd ${ }^{53}$ that a majority shareholder in an SME could easily be viewed as a shadow director. In general the test for shadow directorship seems to be whether the alleged shadow director exercises real influence over the company's management. ${ }^{54} \mathrm{It}$ is not necessary to prove that a person is continually issuing instructions to the board ${ }^{55}$ nor is it essential to show that the alleged shadow director has real influence over every aspect of management. ${ }^{56}$ But control over a majority of board members is a precondition. ${ }^{57}$ Essentially, all relevant factors are to be taken into account when determining whether a shadow directorship has arisen. A holistic perspective is required.

Why do these three categories matter? Well, they are relevant to the issue of stewardship and in particular to the enforcement of legal responsibilities. So, for instance, a de facto director can be disqualified from future office. ${ }^{58}$

48 See MC Bacon Ltd [1990] BCC 78, Re PFTZM Ltd [1995] 2 BCLC 354. Note also Lord Millett's ex cathedra statement on the subject published in [1991] Insolv Pract 14.

49 See F. Bartlett (1994) 10 IL \& P 52. Note also the Financial Law Panel's Shadow Directorships paper published in 1994.

50 It is interesting in the Farepak case that there was no argument that the bank (which was criticized by Peter Smith $\mathrm{J}$ when the disqualification proceedings against the directors were discontinued) was a shadow director. That is probably because its role was largely passive.

51 This seems to have been accepted in principle by Knox $\mathrm{J}$ in $\operatorname{Re} A$ Company (005009 of 1987) [1988] 4 BCLC 424.

52 [2011] NSWCA 109 - discussed by A. Burrow in [2011] Jo of Law Soc of Scotland 50, N. Jamieson and K. Hughes in [2012] Butt Jo of Int Bank and Fin Law 364.

53 [2006] EWHC $1846(\mathrm{Ch})$, [2007] 1 BCLC 618 at paras [90]-[91].

$54 \quad$ See SoSTI v Deverell [2001] Ch 340.

55 But see Re Unisoft Ltd (No. 3) [1994] 1 BCLC 609 (a single act will not suffice).

56 Ultraframe (UK) Ltd v Fielding [2005] EWHC 1638 (Ch).

57 Kuwait Asia Bank v National Mutual Life Nominees [1990] BCLC 868, Re Unisoft Ltd (No. 2) [1994] BCC 766.

58 See Secretary of State for Trade and Industry v Becker [2003] 1 BCLC 555. 
Shadow directors are subject to a wide range of responsibilities. ${ }^{59}$ For someone (such as a liquidator looking to apportion blame for a corporate failure) they offer a range of targets of opportunity for recovery litigation. That is particularly important when a well-to-do entrepreneur has elected to use an undercapitalized limited company as the chosen business vehicle and (in order to further distance himself from liability) has declined to assume a formal position as director.

Moving away from formal legal differentiation, there is also the nominee director to note. ${ }^{60}$ This phenomenon can cause problems for corporate governance, particularly where the nominee is a multiple repeat player merely offering a service to an investor who wishes to remain off the radar. ${ }^{61}$ Some jurisdictions have formal rules dealing with such a status. Other jurisdictions prefer to leave this to jurisprudence of the common law. The main point to note is that a nominee director does not escape the fundamental responsibilities of stewardship simply by virtue of being a nominee of a major stakeholder. Seeking an indemnity before accepting appointment is thus important.

We should also note the position with regard to non-executive directors (NEDs). As far as the law is concerned, these do not form a legally distinct category of director. The Hampel Committee in 1998 looked at NEDs and opposed the establishment of a lesser duty of care. ${ }^{62}$ It is clear that in terms of definition that we are not looking at a term of art. Indeed, the courts ${ }^{63}$ have indicated the difficulty in defining such a person. In spite of this the nonexecutive director is well recognized in practice, particularly in the listed

59 Some of these are mapped out by legislation; others have been the subject of judicial suggestion. The full range is not clear. So in Ultraframe (UK) Ltd v Fielding [2005] EWHC 1638 (Ch) Lewison J opined that the standard fiduciary duties do not apply. This has been questioned. See also Re Mea Corp [2006] EWHC 1846 (Ch), [2007] 1 BCLC 618. But see Companies Act 2006 s. 170(5), an unhelpful provision that leaves the question of which duties apply to the underlying common law. We do know that s. 214 of the Insolvency Act 1986 applies to shadow directors, as do the requirements laid down in SIP 13. Companies Act 2006 s. 858 also applies. On the applicability of s. 190 of the Companies Act 2006 see Re Unigreg Ltd [2005] BPIR 220. Generally see Appendix I of this work.

60 For an excellent review see D. Ahern (2011) 127 LQR 118.

61 This situation was the subject of a major exposé in the Guardian on 26 November 2012 and followed up by a BBC Panorama programme broadcast on the same evening.

62 See Hampel Committee, Committee on Corporate Governance: Final Report (1998) at 3.3. Previously the Cadbury Committee (1992) made the point that all directors (including NEDs) are stewards (see para 1.8). See also Equitable Life Assurance Society v Bowley [2003] EWHC 2263 (Comm) at para [35] per Langley J.

63 See Re Langreen Ltd (21 October 2011, unreported) per Registrar Derrett at para [84]. 
company environment. As to what is expected of a non-executive director, there is no comprehensive statement in law, though Park $\mathrm{J}$ did observe in $R e$ Continental Assurance Co of London plc ${ }^{64}$ that it would be unrealistic to expect them to overrule a specialist director (such as a finance director).

Before leaving this discussion of the family of directors, it is worth noting that in English Law there is no concept of an 'apparent director' or a 'director by holding out' 65 under which a person who does not purport to be a director is represented as such by some other party - this differentiates company law from partnership law. ${ }^{66}$

\subsection{OTHER PLAYERS}

Up to now our focus has been exclusively upon company directors. But our corporate governance system casts its net wider, both linguistically and pragmatically. So, for instance, some statutory provisions have as their target a group designated as company 'officers'. In Appendix I of this work we identify some of these provisions. We can assume from the wording of s. 1173 of the Companies Act 2006 and its equivalents in the Insolvency Act 1986 (s. 251) and Company Directors Disqualification Act 1986 (s. 22C) that company directors would fall within this grouping, but presumably senior executives outside the board might also qualify. All of these provisions referring to officers include managers and secretaries within their catchment area. Certainly, where statutory provisions refer to persons being concerned in the management of a company, an assumption that non-directors are encompassed is irresistible. There is a fair amount of case law arising in a variety of contexts and dealing with who might be seen as a manager, ${ }^{67}$ but it is regrettable that a degree of uncertainty persists in this regard.

\section{6 'INSOLVENCY'}

Increasingly, English law, like other corporate systems, views the use of

64 [2001] BPIR 733 at para [399]. For judicial views on the role of NEDs in Australia see ASIC v Healey [2011] FCA 717.

65 This might explain the generous ruling in Gemma Ltd v Davies [2008] 2 BCLC 281.

66 See Partnership Act 1890 s. 14.

67 See for example Re A Company [1980] 2 WLR 241, $R v$ Campbell [1984] BCLC 83, Re Clasper Group Services Ltd [1989] BCLC 14 and Re Market Wizard Systems Ltd [1998] 2 BCLC 282. For illuminating discussion see T. Clench (2012) 25 Ins Intell 28. 
solvency tests as an important ongoing protection for creditors. This is particularly true in the area of transactions relating to the share capital of a company. So, for example, under Companies Act 2006 s. 642, a declaration of solvency is required to enable a private company to reduce its share capital. Ultimately, whether a company enters members' voluntary liquidation or creditors' voluntary liquidation will depend on whether the directors can vouch for its solvency (see Insolvency Act 1986 ss. 89 and 90).

English law employs two tests to determine whether a company is insolvent. Historically, for these purposes it has utilized the cash flow or liquidity criterion. ${ }^{68}$ A company is insolvent in this sense according to s. 123(1) of the Insolvency Act 1986 if it cannot, or will not, pay its debts as they fall due. Thus, an asset-rich company that wilfully refuses to pay an undisputed debt can find itself being characterized as insolvent under the law, even though it is manifestly in rude financial health. ${ }^{69}$

As a result of reforms enacted in 1985, we now also use a balance sheet criterion, which prima facie involves a mathematical comparison of assets and liabilities, including contingent liabilities. This criterion to measure insolvency is now to be found enshrined in s. 123(2) of the Insolvency Act 1986. Recent consideration to this test was given by the Court of Appeal in BNY Corporate Trustee Services Ltd v Eurosail-UK 2007-3BL plc. ${ }^{70}$ Here Lord Neuberger MR stressed that this test is to be applied in a flexible fashion and should not be seen as a purely mathematical exercise. Commercial common sense should be taken into account. Whilst this approach is commendable for its realism and for taking a number of firms outside insolvency territory, practitioners are concerned that it has generated uncertainty. ${ }^{71}$ The moment a company can be said to be insolvent can be critical in determining the applicable duties of directors and the nature of the professional advice given to such directors. The case in question is awaiting the outcome of a further appeal to the Supreme Court and it will be interesting to see if these concerns are addressed.

We should enter a note of caution here. Both tests are not employed in every instance where issues of directorial liability fall to be determined. Thus, Professor Goode has pointed out ${ }^{72}$ that it is only the balance sheet test that has any relevance for determining wrongful trading liability. That may be the subject of a range of opinions but the general point made is accurate - each situation needs to be reviewed on its individual basis.

68 Re Patrick and Lyon Ltd [1933] Ch 786.

69 See Cornhill Insurance plc v Improvement Services Ltd [1986] BCLC 26.

70 [2011] EWCA Civ 227, [2011] BCC 400. See also Re Cheyne Finance [2007] EWHC 2402 (Ch), [2008] BCC 182.

71 See D. Henderson (2011) 24 Ins Intell 54.

72 See [1989] JBL 436. 
We should also observe that prospective insolvency may be relevant in some contexts. So the court can place a company into administration using the Insolvency Act 1986 Schedule B1 para 11 procedure if the company is likely to become insolvent. The courts are quite receptive on friendly applications to reach such a conclusion; less so where the application may be construed as hostile. ${ }^{73}$

There are other tests for what constitutes insolvency for the purposes of particular pieces of legislation. Thus there is a test under s. 183 of the Employment Rights Act $1996^{74}$ and one for the purposes of the Pensions Act $2004 .^{75}$ Within the European Union we could also note Art 2 of the EC Insolvency Directive (2008/94).

Looking beyond legislation, commercial documentation may employ a customized definition of what constitutes an insolvency event for the particular relationship - for example one finds such definitions in contractual break clauses or in a finance agreement.

\subsection{INSOLVENCY PRACTITIONERS ${ }^{76}$}

Apart from directors, the other human actors that will be the primary focus of our attention are insolvency practitioners. We stress the human characteristic here; English law does not permit a firm, whether corporate or not, to hold an insolvency office. ${ }^{77}$ The post of liquidator, etc, must be held by a natural person. ${ }^{78}$ Although there are clear benefits ${ }^{79}$ flowing from this idea of an ad personam appointment, this can cause practical difficulties, particularly as the

73 See the case of Re Colt Telecom (No 2) [2002] EWHC 2815 (Ch), [2003] BPIR 324 - decided under the old administration order regime but still relevant for these purposes.

$74 \quad$ See Secretary of State for Trade and Industry v Key [2004] BPIR 214.

75 Section 121 - see the discussion in Re Olympic Airlines SA [2012] EWHC 1413 (Ch), [2012] BPIR 1163.

76 See D. Milman [2012] 321 SMCLN 1 for a review of current issues. Excellent background on the regulatory context can be gleaned from the pieces by V. Finch in [1998] JBL 334 and [2012] JBL 645.

77 This is not the position overseas. Indeed, within English law it is possible to cite stewardship examples where a corporate body can act - witness Trustee Act 1925 s. 68 .

78 The one exception is the official receiver - see Insolvency Act 1986 ss. 399-401. It is interesting to compare this insistence on human agency with the more liberal approach to the appointment of trustees - see Trustee Act 1925 s. 68.

79 See Reid and Stephen, Noters [2010] CSOH 138 where the court observed that an office-holder cannot simply walk away from the responsibility whilst leaving matters in the hands of a co-appointee. 
reality is that the appointment is managed by an insolvency firm, of which the appointee is but a member. If an insolvency practitioner dies in post, or retires, or leaves the firm to move to fresh pastures, there will be a need for replacement. As individual office-holders invariably hold multiple offices concurrently, the replacement problem is magnified. In response to these inevitable facts of life, the law has had to introduce mechanisms to deal with 'block transfers' of insolvency offices. ${ }^{80}$ The overriding imperative here is that the insolvent estate should not bear the cost of this change of stewardship - see Insolvency Rule $7.10 \mathrm{D}(4)$. The courts will also be careful to examine the circumstances behind the block transfer and will not simply rubber stamp the nomination of the outgoing office-holder. ${ }^{81}$ The views of the relevant recognized professional body (RPB) may be taken into account when any substitution is being considered.

Holding office as an insolvency office-holder is something that needs careful regulation. So under s. 164 of the Insolvency Act 1986 it is an offence to offer bribes to procure appointment as a liquidator. If, in spite of this, a liquidator has improperly solicited appointment, any claim to remuneration will be jeopardized (Insolvency Rule 4.150).

One problem we have in dealing with the law on insolvency practitioners is the profusion of official terms that can be used to describe them. So in s. 388 the term 'insolvency practitioner' is used. We then have the category of 'office-holders' as defined somewhat confusingly in different ways in ss. 230-37 of the Act. There is then the common-law idea of 'officers of the court', which is wider than we might anticipate. Finally we have the very broad designation of 'appointee' as used under the Practice Direction on Insolvency Proceedings. ${ }^{82}$ If we take administrative receivers as an example, we find that they are insolvency practitioners and office-holders (for some purposes) but are not officers of the court nor appointees.

The insolvency profession itself is a late nineteenth-century professional manifestation. ${ }^{83}$ The profession grew in importance throughout the twentieth century. That said, it only assumed the mantle of a fully fledged profession ${ }^{84}$

80 The courts lead the way with a number of significant authorities - see Donaldson v O'Sullivan [2008] EWCA Civ 879, [2009] BCC 99. There is now specific treatment of this issue in Insolvency Rules 7.10A-7.10D as inserted by Insolvency (Amendment) Rules 2010 (SI 2010/686).

81 See ACCA v Koumettou and Morfakis [2012] EWHC 132 (Ch) and ICAEW v Webb [2009] EWHC 3461 (Ch). Compare Re AJ Adams Builders Ltd [1991] BCC 62.

82 [2012] BPIR 409 para 1.1(11).

83 For a historical perspective see J. Flood and E. Skordaki, Insolvency Practitioners and Big Corporate Insolvencies (1995) (ACCA Research Report No. 43). Note also V.M. Lester, Victorian Insolvency (1995).

84 See G. Borrie [1984] JBL 111 at 113 for comment. 
with monopoly standing in the wake of the implementation of the Cork Report (1982) ${ }^{85}$ It successfully rebranded ${ }^{86}$ itself in the latter half of the 1990 s so as to have an explicit focus on business recovery. One can see the public relations advantages in this marketing strategy. Turnaround is clearly an important goal (and one that few people will criticize), but the less glamorous liquidation role still retains its importance, as all of the statistical evidence on UK corporate insolvencies confirms. There are more insolvent liquidations annually than all other corporate insolvency regimes combined together. Moreover, many administrations (and CVAs) are little more than disguised liquidations. That is particularly so since administration was remodelled by s. 248 of the Enterprise Act $2002 .{ }^{87}$ Business rescue in reality is the exception rather than the rule. There is nothing unusual about this; it is the pattern replicated across the globe. Furthermore, there are a number of businesses where rescue has been but a temporary stay of execution. ${ }^{88}$ To associate insolvency with 'rescue' may therefore be an illusion. This may present an uncomfortable truth for policymakers and the insolvency profession who have invested heavily in the idea of business rescue, even to the point of rebranding their professional association. ${ }^{89}$ Devotees of the potential of creative destruction would not be alarmed by the failure of the law to rescue distressed firms - the economic opportunity could be exploited by a new market entrant.

The Office of Fair Trading (OFT) Market Study Report ${ }^{90}$ in 2010 is valuable in placing the different insolvency regimes in context. From that report we find out in para 3.8 that some 50 per cent of fee income is derived from administrations. We also learn that 29 per cent of administrations have a CVL outcome. This report also produces the impressive statistic that insolvency practitioners realize some $£ 5$ billion in assets every year at a cost of $£ 1$ billion.

There are surprisingly few insolvency practitioners who take office. Current figures suggest that there are at present only some 1800 insolvency

85 Cmnd 8558. For contemporary analysis see D.M. Hare and D. Milman (1983) 127 Sols Jo 230-335 seriatim.

86 The key representation organization is the Association of Business Recovery Professionals (or R3). Up to 2000 it was called the Society of Practitioners of Insolvency (which more accurately represented its remit).

87 But there are still important differences between these two regimes - see the comments of David Richards J in Heis v MF Global Inc [2012] EWHC 3068 (Ch) at para [52]. For analysis of the 2002 Act see V. Finch [2003] JBL 527, J. Armour, A. Hsu and A. Walters [2008] 5 ECFLR 148. The Insolvency Service also published a survey on the impact of this legislation in 2008.

88 See L. Lo Pucki and J.W. Doherty, Professional Fees in Corporate Bankruptcies (2011) where it is pointed out (at 6) that 26 per cent of US companies undergoing Chapter 11 are required to seek a further restructuring within five years.

89 See the marketing article by W. Black in [2012] (Autumn) Recov 28.

90 See The Market for Corporate Insolvency Practitioners (2010) (OFT). 
practitioners in the country and of these only 1341 are active. ${ }^{91}$ With the high number of insolvencies occurring each year, this can lead to the phenomenon of multiple posts in respect of many companies being held concurrently by the same individual. Accordingly, critics $^{92}$ have suggested that more competition is needed in the market for insolvency services and that this might be achieved through an increase in the number of insolvency practitioners. Clearly the bulk of licensed insolvency practitioners are associated with the large firms of accountants ${ }^{93}$ and the impact of 'bank panels' should be noted, but there is a healthy group of smaller firms who have developed niche specialisms. Another strategy has been to introduce turnaround specialists into the market, such as company doctors into the field, but these still cannot hold a formal insolvency office as a liquidator, administrative receiver or administrator. The Insolvency Act 2000 made strides in this direction by introducing through s. 4(4) a new s. 389A into the Insolvency Act 1986, but such individuals still cannot take formal appointments as this provision has not been brought into force. The problem seems to be that the legislation does not contemplate selective authorization of permitted roles. Consequently, their role is restricted to advising distressed firms in the hope that formal insolvency can be avoided. We will examine the consequences of this role later.

There is also a gender gap phenomenon that should be confronted. Current estimates suggest that only 21 per cent of insolvency practitioners are female ${ }^{94}$ - this compares unfavourably with female representation in similar allied professions, such as law and accountancy. The gender issue is being taken seriously by the insolvency practitioner profession and also by the Insolvency Service, which publishes data on its own gender profiling. ${ }^{95}$

In terms of regulation we are faced with a balkanized structure with no less than eight regulators playing a role. There are seven recognized professional bodies (RPBs), ${ }^{96}$ plus the Insolvency Service, which still retains a direct

912011 Insolvency Service Annual Report on IP Regulation (2012) at 4. In 1994 it was calculated that the figure was 1925 - see J. Flood and E. Skordaki, Insolvency Practitioners and Big Corporate Insolvencies (1995) (ACCA Research Report No. 43).

92 This concern seems to be implicit in the setting-up of the 2010 OFT Market Study review.

93 This potentially could raise issues of conflict of interest - the effective use of so-called 'Chinese walls' could be important here - see Bolkiah v KPMG [1999] 2 AC 222.

94 See R3 publication The Value of the Insolvency Industry (2008) at pp. 3 and 24. In the mid-1990s the figure was estimated to be as low as 5 per cent. All of the evidence suggests travel is being made in the right direction.

95 See the Diversity and Equality heading on the Insolvency Service website, where details of an annual data survey appear.

96 See Insolvency Act 1986 s. 391. 
licensing role. This situation has attracted criticism but there are some powerful players at work here who are reluctant to cede territory in a turf war. The role of the Insolvency Service in terms of authorization is likely to be reviewed in the future as it does represent an anomaly.

The profession is well represented by trade bodies such as R3 and the ILA. These are influential pressure groups. Their impact can be attested by the speedy enactment of the Insolvency Act 1994 and in their efforts to restrict the reforms in the Enterprise Act 2002, particularly with regard to administrative receivership. They serve the public interest in disseminating valuable information about current insolvency developments. The R3 Technical Bulletin celebrated its $100^{\text {th }}$ edition in October 2012. In so doing, these organizations inform both their members and benefit the public at large.

\section{8 'STEWARDSHIP'}

A 'steward' is defined in Jowitt's Dictionary of English Law ${ }^{97}$ as a ward or keeper, or a person appointed in the stead of another. The term stewardship can be applied to a multiplicity of legal relationships. ${ }^{98}$ Ideas of stewardship are very much in vogue at present across a diverse range of contexts. ${ }^{99}$ We are all familiar with situations of stewardship arising in English law. The trustee acting under a trust on behalf of beneficiaries is perhaps the most obvious scenario. But there are others: for instance, guardians acting for wards, those representing persons lacking mental capacity, and personal representatives of the deceased. These are all general forms of stewardship. A more specialized and attenuated variant is found in the law of bailment, where a bailee is responsible for the safe custody and transmission of goods entrusted to its care by the bailor.

In stewardship situations it is not uncommon to find the steward invested with the legal title of property held for the benefit of the protected party - e.g. in the classic trust scenario. But this is not an absolute prerequisite - both directors and insolvency practitioners are indisputably stewards, but it would be unusual to find them holding the legal title of property belonging beneficially to the company. ${ }^{100}$ What matters here is the de facto control of property.

$97 \quad 3^{\text {rd }}$ ed., 2010. Vol 2. See also S. Ali [2012] Jo of Fin Crime 207.

98 Soren Holm mentions 13 possible meanings of the word 'steward' in his piece in [2011] 62 NILQ 617.

99 Witness the special issue of the Northern Ireland Legal Quarterly in 2011 (vol 62 part 5) devoted to stewardship in the medical context.

100 So for instance the controller of a company can steal company property (Attorney General's Reference (No. 2 of 1982) [1984] QB 624) and has no insurable 
What we will seek to do in this study is to locate the position of the company director and insolvency office-holder within that broad stewardship tradition and to examine the extent to which general principles of stewardship (if any such exist) apply. We shall also note situations where stewardship responsibilities towards the company (however defined) may come into conflict with stewardship responsibilities owed to other stakeholders.

\subsection{STAKEHOLDER GROUPS}

In our definition of governance we introduced the term 'stakeholder'. ${ }^{101}$ This again is an example of modern terminology. Clearly, it encompasses shareholders but it goes beyond that. A perusal of the minutiae of s. 172 of the Companies Act 2006 will provide a sense of how expansive this concept has become with business counterparties, local communities and the environment being potential candidates as stakeholders.

Creditors today are indisputably viewed as stakeholders, whether the company is solvent or not. That was not always so - in the past they were denied the opportunity to challenge ultra vires business activities. ${ }^{102}$ Things have moved on. Indeed, as the company degenerates, they become the dominant stakeholders. Accordingly, their consent will be required for any sort of restructuring - see Companies Act 2006 s. 899. Creditors may be contractual counterparties or involuntary creditors such as tort victims or the revenue authorities. We need to be careful here in placing all creditors into a single class. This note of caution is reinforced when one considers the statement that English law can be viewed as 'pro creditor'. That is a puzzling statement when one considers the poor returns enjoyed by unsecured creditors on corporate insolvency. What this statement really implies is that English law is pro secured creditor. That is true, though there has been some withdrawal from that sectarian position in the wake of the Enterprise Act 2002.

Employees fall within the stakeholder group. Their rights as suppliers of labour may be protected on a restructuring and they enjoy the right, through their representatives, to be consulted on any potential job losses. ${ }^{103}$

interest in company property (Macaura v Northern Assurance Co [1925] AC 619). This separation of ownership and control of company property is a central governance issue - see Chapter 2.

101 See Will Hutton, The Stakeholding Society (1999).

102 Mills v Northern Rwy of Buenos Aires (1870) 5 Ch App 621.

103 I reviewed this issue in 'From Servant to Stakeholder: The Employee Interest in Company Law', Chapter 8 in D. Feldman and F. Meisel, Corporate and Commercial Law: Modern Developments (1995). 


\subsection{THE PUBLIC INTEREST ${ }^{104}$}

The material covered in this study will be primarily within the domain of private law in that private interests are to the fore. But that is not to say that the element of public interest is irrelevant. In a capitalist society there is a clear public interest in encouraging enterprise and responsible risk-taking. Limited liability is essentially available as a matter of public policy choice, with that choice being made critically by the UK Parliament in 1855. A public policy choice engages public interest. Limited liability therefore needs to be monitored by the state: any suggestion of abuse of this economic concession might result in an informal investigation under s. 447 of the Companies Act 1985 (reconstituted by s. 21 of the Companies (Audit, Investigations and Community Enterprise) Act 2004). ${ }^{105}$ Cooperation by company officers with such an investigation is compulsory. ${ }^{106}$ In the wake of such a gathering of evidence a petition may be presented under s. 124A of the Insolvency Act 1986 for a winding-up in the public interest. ${ }^{107}$ According to Insolvency Service Annual Report, ${ }^{108}$ this power was exercised on 355 occasions in the year 2011-12 (for perspective, compare this statistic with the 2.5 million registered companies on the register in that same year). The primacy of the public interest was confirmed recently in Secretary of State for Business, Innovation and Skills v Top Choice Wholesale Ltd, ${ }^{109}$ where the court confirmed that a s. 124A petition could be presented notwithstanding an extant winding-up petition presented by a creditor. The power can be exercised not merely against limited companies but also against LLPs. ${ }^{110}$ Such a form of liquidation does not however come within the embrace of the EC Regulation on Insolvency Proceedings (1346/2000). ${ }^{111}$ As winding-up is a draconian step, there is the possibility of the concerns being addressed through the acceptance of formal undertakings about the future business operations of the company. ${ }^{112}$

104 See Cork Committee (Cmnd 8558, 1982) Chapter 43.

105 Minor amendments were made by s. 1038 of the Companies Act 2006.

106 See Companies Act 1985 s. 453C and Secretary of State for BIS v Scaggs [2012] EWHC $3120(\mathrm{Ch})$ where proceedings for contempt followed acts of non-cooperation.

107 See V. Finch [2002] Ins Law 157, A. Keay [2000] 51 NILQ 509.

108 See Insolvency Service Annual Report and Accounts 2011/12 (HC 358) at p. 32.

109 [2012] EWHC 1262 (Ch). See also Re PGMRS Ltd [2010] EWHC 2983 (Ch), [2011] BCC 368 and Re Treasure Traders Ltd [2005] EWHC 2774 (Ch). Under para 82 of Sched B1 of the Insolvency Act 1986 a company in administration can still be wound up in the public interest.

110 Re Inertia Partnership LLP [2007] EWHC 539 (Ch), [2007] BCC 656.

111 Re Marann Brooks CSV Ltd [2003] BCC 239 per Patten J at para [34].

112 See Bell Davies Trading v SoSTI [2004] EWCA Civ 1066, [2005] BCC 564. 
There is a public interest involved when one calculates the costs to the national exchequer in protecting society from the harm that can be caused by unfit directors. ${ }^{113}$ The director disqualification regime, especially where there is a disqualification based upon s. 8 of the Company Directors Disqualification Act 1986, is posited upon the protection of the public, rather than on penalizing errant directors. There is a clear public interest at stake when one takes into account the financial costs of taking measures to combat errant directors. The public interest element in liquidation was stressed by Lord Millett in Official Receiver $v$ Wadge, Rapps and Hunt ${ }^{114}$ when characterizing the essence of the liquidation process. The role of the official receiver in winding up hopeless cases where the private sector is not interested could be mentioned here. But we must be careful when discussing public interest as what constitutes public interest is not always the subject of consensus - witness the different interpretations in Whitehouse $v$ Wilson. ${ }^{115}$

Conversely, the state has an interest in trying to ensure that companies in difficulty survive, because of the negative impact upon employment where a business fails (thereby causing further indirect loss to the exchequer). Companies are major tax-gatherers for the state, which therefore has a creditor stakeholder interest in every company. This on average amounts to nearly 25 per cent of the unsecured debt. The desire on the part of the state to preserve companies is manifested in a range of contexts. For example, under s. 17 of the Company Directors Disqualification Act 1986, a director of a failed company who has consequently been disqualified can apply for special leave to remain as director of another solvent company. ${ }^{116}$ In making such an application it is not uncommon for the applicant director to argue that this second concern would also fail without his/her input. ${ }^{117}$ In granting leave under s. 17, the public interest can be protected by the introduction of an upgraded corporate governance regime. ${ }^{118}$ The courts have shown themselves receptive to

113 Hence the National Audit Office Reports in the 1990s investigating the costs of the court-based director disqualification regime. See for analysis A. Hicks, Disqualification of Directors: No Hiding Place for the Unfit? (1998) (ACCA Research Report No. 59).

114 [2003] UKHL 49, [2004] 1 AC 158. Lord Millett was merely reiterating the views he expressed a decade earlier as Millett $\mathrm{J}$ in Re Barlow Clowes (Gilt Managers) Ltd [1991] BCC 608 at 616-17.

115 [2007] BPIR 230.

116 See generally T. Clench (2008) 21 Ins Intell 113, A. Belcher [2012] 16 Edinburgh Law Rev 386. A similar provision can be found in Ireland in s. 160(8) of the Companies Act 1990.

117 See for example SoSTI v Barnett [1998] 2 BCLC 64 (where the sob story failed).

118 See for example Re Gibson Davies Ltd [1995] BCC 11 (some nine conditions were attached to the leave). 
such an argument. Any leave granted under s. 17 may be general or simply a specific authorization to exercise certain directorial powers (for example instructing solicitors to act on behalf of the company ${ }^{119}$ ). Leave applications under s. 17 are few in number when compared with the overall number of disqualifications, a point disclosed in a recent study by Alice Belcher. ${ }^{120}$

Again, in $R v$ Cotswold Geotechnical Holdings Ltd, ${ }^{121}$ Field $\mathrm{J}$ in the Crown Court noted that, under sentencing guidelines, fines imposed for a conviction for corporate killing under the Corporate Manslaughter and Homicide Act 2007 should not be so great as to put a company out of business. That said, if a terminal fine was appropriate, that sanction should not be eschewed. The $£ 385000$ fine imposed by Field J, which was upheld on appeal, ${ }^{122}$ contributed to the demise of the offending company, which went into liquidation shortly thereafter.

The public interest is not merely protected by traditional legal institutions. It is a vital function of the role of RPBs - this point was stressed by Lord Slynn in ICAEW v Customs and Excise. ${ }^{123}$

\subsection{CHANGING TECHNOLOGIES ${ }^{124}$}

One problem that both directors and insolvency practitioners have had to grapple with has been the changing technological climate in which they have to operate in. This is particularly true of the revolution in communications technology over the past two decades. The paper-based system for communication, upon which the 1986 regime was modelled, has become an anachronism with the widespread use of modern communications technology in business. To what extent can directors and insolvency office-holders take advantage of such changes in conducting their stewardship of a limited company in a more efficient manner and thereby save administration costs? Caution is the key word here. Although the courts might be prepared to stretch the meaning of a statutory provision to reflect technological evolution, ${ }^{125}$ there is no guarantee that

119 See Re Portland Place Historic House Ltd (unreported, 20 June 2012).

120 See [2012] 16 Edin Law Rev 386.

121 [2011] All ER (D) May 100.

122 [2011] EWCA Crim 1337.

123 [1999] UKHL 19, [1999] STC 398.

124 For general background see D. Milman, National Corporate Law in a Globalised Market (2009) at 57.

125 See $R v$ Taylor [2011] EWCA Crim 728, [2011] 1 WLR 1809, where the concept of 'books or paper' when used in the context of s. 206 of the Insolvency Act 1986 was held to include computer records. A similarly flexible approach was taken by HHJ Purle in Re Advent Computer Training Ltd [2010] EWHC 459 (Ch), [2011] BCC 
they will always be so accommodating. That said, the legislature has shown itself increasingly willing to embrace new technology to facilitate the stewardship role. So, from the viewpoint of directors, s. 360A of the Companies Act 2006 permits remote company meetings. As far as insolvency practitioners are concerned, there were a raft of reforms introduced by the Insolvency (Amendment) Rules 2010 126 and the Legislative Reform (Insolvency) (Miscellaneous Amendments) Order 2010 ${ }^{127}$ designed to make greater use of electronic communication during the conduct of the administration of an insolvency. So, for instance, remote attendance of creditors may be permitted in $\mathrm{s}$. 246A of the Insolvency Act 1986 and an insolvency practitioner may make use of websites to communicate with stakeholders under the provisions in s. 246B of the Act. It is too early to determine how widely these concessions are being used, but contacts with IPs suggest that this has been a positive move.

Technological change may not simply be a matter of easing burdens. So, for instance, the Companies (Trading Disclosure) (Insolvency) Regulations $2008^{128}$ increased the disclosure obligations of insolvency practitioners where websites and electronic means of communication were being used to deal with customers.

44. In Re Sporting Options plc [2004] EWHC 3128 (Ch), [2005] BPIR 435, one gets the feeling that Mann J was trying to be helpful but nevertheless felt constrained by the law.

126 SI 2010/686.

127 SI 2010/18.

128 SI 2008/1897. 